\title{
MED12 wt Allele
}

National Cancer Institute

\section{Source}

National Cancer Institute. MED12 wt Allele. NCI Thesaurus. Code C98211.

Human MED12 wild-type allele is located in the vicinity of Xq13 and is approximately 24 $\mathrm{kb}$ in length. This allele, which encodes mediator of RNA polymerase II transcription subunit 12 protein, is involved in the modulation of RNA polymerase II activity. Mutation of the gene is associated with both Opitz-Kaveggia syndrome and Lujan-Fryns syndrome. 